\title{
Methane Emission and Quantification from Flooded and Non-Flooded Paddy Field at Kedah Malaysia
}

\author{
P. K. Lo, W. Z. Lim, C. A. Ng, S. P. Tan, T. L. Chew, and C. Y. Chong
}

\begin{abstract}
In order to quantify the methane emission from paddy fields with different irrigation methods and to study the potential of using the alternate flooding strategy in suppressing the methane emission, field experiments were conducted in Nestlé Rice Experimental Station located in Sik area, Kedah, Malaysia. Closed-chamber method was used in this research study. By employing transparent chambers, methane gas was sampled from two paddy field plots with different irrigation methods. The methane gas was collected at the paddy plots and analyzed for its concentration. It was done continuously for 84 days after seeding stage and stopped before the ripening stage of paddy. The similar increasing trend of methane emission was observed from each paddy field plot from the tillering stage till flowering stage of paddy. However, the methane emission rate from non-flooded plot with the water saving irrigation method was found relatively low compared to the flooded plot.
\end{abstract}

Index Terms-Closed-chamber method, water saving irrigation method, methane emission, aeranchyma tissues.

\section{INTRODUCTION}

Methane is a greenhouse gas which can trap infrared radiation and induce the increment of earth's temperature. Over a 100-year horizon, 1 ton of $\mathrm{CH}_{4}$ will induce a global warming effect equivalent to 21 tons of carbon dioxide $\left(\mathrm{CO}_{2}\right)$ [1]. Methane may emit either from natural or anthropogenic sources. The natural sources emitting methane include wetland, ocean, permafrost, lakes, wildfires, wild animals, and gas hydrates.

The global warming potential (GWP) of $\mathrm{CH}_{4}$ is 25 times that of $\mathrm{CO}_{2}$ [2]. The environments of growing rice are different within and between countries but they were categorized according to water regime, drainage, temperature, soil types and topography. Paddy fields are traditional rice farming fields in Southeast Asia and rice paddies are major food sources in Asia region. But, South East Asia contributes $90 \%$ to the global rice methane emission and emits

Manuscript received June 9, 2015; revised August 5, 2015. This work was supported by Nestlé Manufacturing (M) Sdn Bhd.

P. K. Lo and W. Z. Lim are with the Department of Petrochemical Engineering, Faculty of Engineering and Green Technology, University Tunku Abdul Rahman, Jalan Universiti, Bandar Barat, 31900 Kampar, Perak, Malaysia (e-mail: lopk@utar.edu.my).

C. A. Ng and S. P. Tan are with the Department of Environmental Engineering, Faculty of Engineering and Green Technology, University Tunku Abdul Rahman, Jalan Universiti, Bandar Barat, 31900 Kampar, Perak, Malaysia (e-mail: ngca@utar.edu.my).

T. L. Chew is with the Chemical Engineering Department, Faculty of Engineering, Universiti Teknologi Petronas, 32610 Bandar Seri Iskandar, Perak, Malaysia (e-mail: thiamleng.chew@petronas.com.my).

C. Y. Chong is with the Nestlé Manufacturing (M) Sdn Bhd, Mutiara Damansara, 47810 Petaling Jaya, Selangor Malaysia (e-mail: chinyin.chong@my.nestle.com). approximately $10,000 \mathrm{~kg}$ of methane per kilometer squares [3].

Water management has been recognized as one of the most important practices that affect $\mathrm{CH}_{4}$ emissions from paddy fields [4]. Conventional irrigation of rice fields requires the consumption of large amounts of water. The development of efficient irrigation water management practices such as water saving irrigation method may reduce $\mathrm{CH}_{4}$ emissions from paddy field.

In paddy fields, there are many microorganisms, namely methanogen, found to undergo anaerobic conditions in the water due to the slow diffusion of oxygen through water. Methanogenesis activities are decomposition of organic matters by methanogens in the soils under anaerobic state due to the flooded conditions of paddy fields. Methanogenesis is one of the anaerobic activities of microorganisms that can produce methane and is responsible for greenhouse effect [5].

Currently the continuous flooded method is practiced by local farmers on their paddy fields and it does contribute to methane emission and global warming. Besides, due to the scarcity of freshwater resources available for irrigated agriculture and escalating food demand around the world in the future, it will be necessary to produce more food with minimum water usage [6]. Therefore, this project is to study the application of water saving irrigation method on local paddy fields and its effect on reducing methane emission to the environment.

\section{MATERIALS AND METHODS}

\section{A. Site Description}

The trial paddy fields owned Nestlé Manufacturing (M) Sdn Bhd were selected for methane sampling and were located at Sik, Kedah (5'46’21.5”N, 10042’32.5” E). A total of two plots, namely Plot A and Plot B respectively, were selected to sample the gas. Plot A was the controlled plot which was always flooded. Plot B was the plot using water saving irrigation method, the plot was switched to non-flooded 50 days after seeding. Types of rice variety used were Clearfield ${ }^{\circledR}$ rice and the time taken for this variety to mature and ready for harvest was approximately 90 days.

\section{B. Methane Flux Chambers Setup}

Six transparent acrylic chambers were designed to collect the methane gas. Three chambers were allocated in each paddy plot. Any existing vegetation other than rice paddies was cleared on the spot to place the chambers. The chambers in each plot were placed with a distance of $1 \mathrm{~m}$ in a straight line. The chambers were pushed into ground field for the depth of about $50 \mathrm{~cm}$ deep. Each chamber was equipped with 
two thermometers. Air thermometer was hung at the chamber and another one was namely as the soil thermometer was put into the rice paddy field where the chamber was set up. A ruler attached to the chamber was used to measure the height of the water. The chambers were left to settle for about 24 hours before gas sampling was started. Gas sampling was prepared by assembling the vacuum gas bags to each chamber and the bags were placed against the corresponding chamber for gas collection.

\section{Gas Sampling}

Gas in the chamber was collected in the morning from 10 am to 11 am once a week. Vacuum gas bags were used to collect the gas. The vacuum gas bag was attached to portable vacuum pump with a pipe connecting the inlet of the bag and opening valve of the chamber. Gas in the chamber was pumped into the vacuum gas bag by using a portable vacuum pump. Before the gas sampling was started, temperatures of the soil and air were recorded using the thermometers placed in the chamber. The temperatures recorded throughout the experiment were used for methane flux calculation.

\section{Gas Sample Analysis}

The total gas samples collected in vacuum gas bags were analyzed by using gas chromatography. For methane, RT molecular sieve 5A PLOT capillary column (Restek) was used and the detector used was flame ionization detector (FID). Nitrogen gas $\left(\mathrm{N}_{2}\right)$ was used as carrier gas with flow rate of $40 \mathrm{~mL} / \mathrm{min}$. The operating temperature for gas chromatograph injector, oven and detector was $35^{\circ} \mathrm{C}, 30^{\circ} \mathrm{C}$ and $200^{\circ} \mathrm{C}$ respectively. Peak areas for each gas sample were integrated automatically on the chromatograms by chromatography software. All integrations were double-checked manually and adjusted if necessary. Following that, peak areas were crosschecked to a $10 \mathrm{ppm}$ methane gas calibration peak to verify that the sample collected was methane gas. Furthermore, by comparing the 10 ppm methane calibration peak, concentration of methane gas in the sample collected was calculated. Lastly, the methane gas concentration for each sampling times interval was analyzed and linear regression line was plotted.

\section{E. Methane Flux Calculation}

The flux of the methane emission was calculated according to the following equation:

$$
\text { methane flux }\left(\frac{m g}{m^{2} h}\right), f=\frac{10^{-5} \times \mu \bar{P}}{R \times T} \times H \times \frac{d C}{d T}
$$

where, $\mu$ is the gas molecular weight of methane (16.123 $\mathrm{g} / \mathrm{mol}) ; \bar{P}$ is the mean air pressure in the chamber $(1.01325$ $\times 10^{5} \mathrm{~Pa}$ for non-high elevation area); $R$ represents the universal gas constant $(8.31441 \mathrm{~J} / \mathrm{mol} \cdot \mathrm{K}) . \quad T$ is the temperature in Kelvin. $H$ is the effective height in meter of the chamber when sampling; $d C / d T$ is the increase rate of methane concentration in the chamber which is the slope of the linear regression of methane concentration on time as time approaches zero [7].

\section{F. Methane Flux from Paddy Field}

The methane flux measurements for the paddy field were started from January till March 2014. The irrigation method planned was as follows:

1) Two test plots were flooded until day 50 after seeding, and after day 50 after seeding, Plot A was remained as flooded plot while Plot B was switched to water saving irrigation method which only sufficient water was provided to maintain the moisture of soil.

2) The gas samples collected was analyzed via gas chromatography method as shown in Fig. 1, with methane peak was detected. This finding was compared to calibration peak (Fig. 2). The methane gas concentration of each sample was tabulated in Table I and the calculation was based on the $10 \mathrm{ppm}$ methane calibration peak area as shown in Fig. 2. Fig. 3 shows a graph plotted by using the methane concentration against time intervals of gas sampling and the gradient of line was the $d C$ / $d T$ value in (1). The flux calculated was linked to the effect of paddy growth stage and the water levels in plots which had affected the methane emission rate.

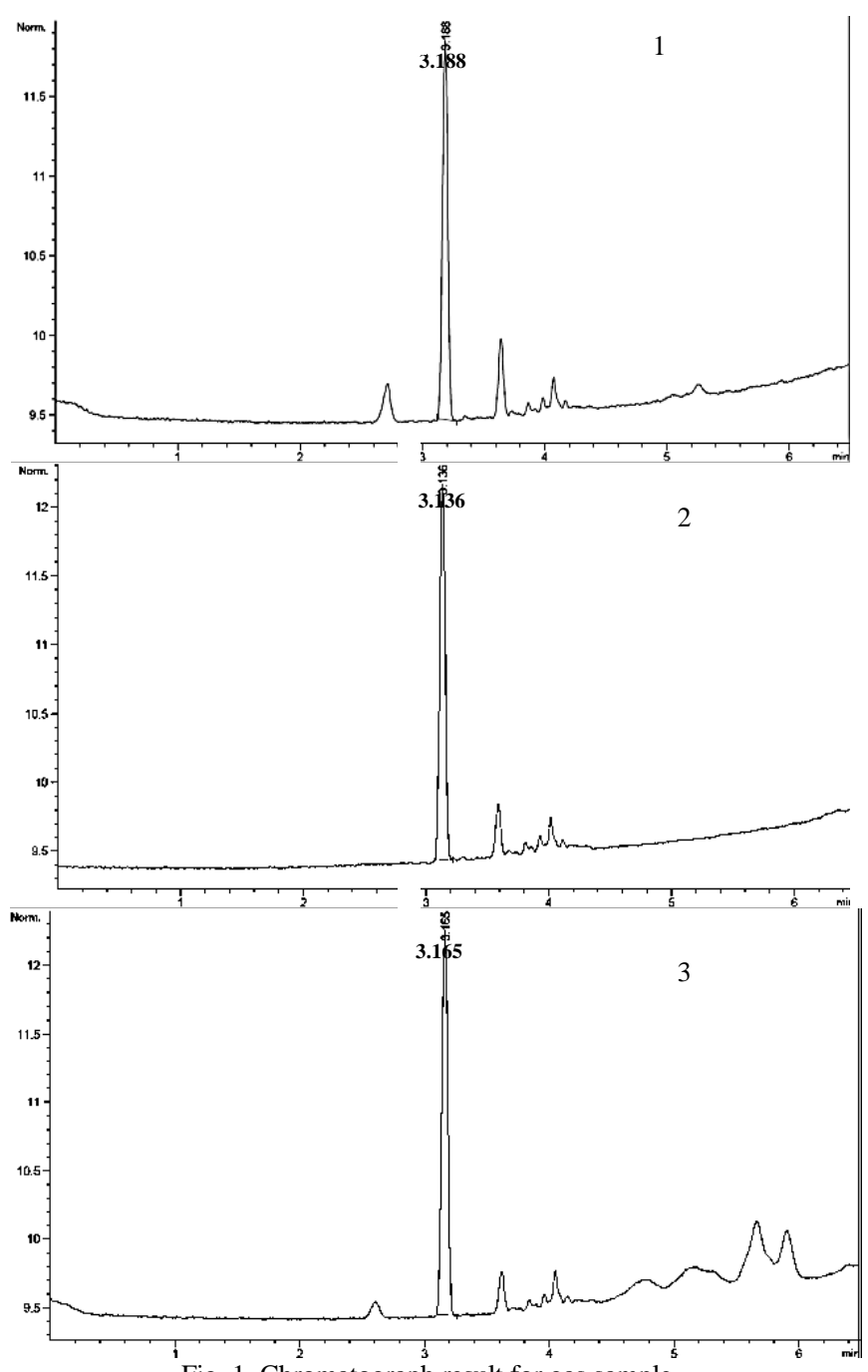

Fig. 1. Chromatograph result for gas sample.

\begin{tabular}{llll}
\multicolumn{3}{c}{ TABLE I: METHANE CONCENTRATION OF CHAMBER A1 IN PLOT A } \\
\hline \hline $\begin{array}{l}\text { Chamber } \\
\text { A1 }\end{array}$ & $\begin{array}{l}\text { Time intervals of gas } \\
\text { sampling, hour }\end{array}$ & Area & $\begin{array}{l}\text { Methane } \\
\text { concentration, ppm }\end{array}$ \\
\hline 1 & 0 & 7.2 & 377.1 \\
2 & 0.167 & 8.5 & 443.2 \\
3 & 0.333 & 9.4 & 489.9 \\
\hline
\end{tabular}




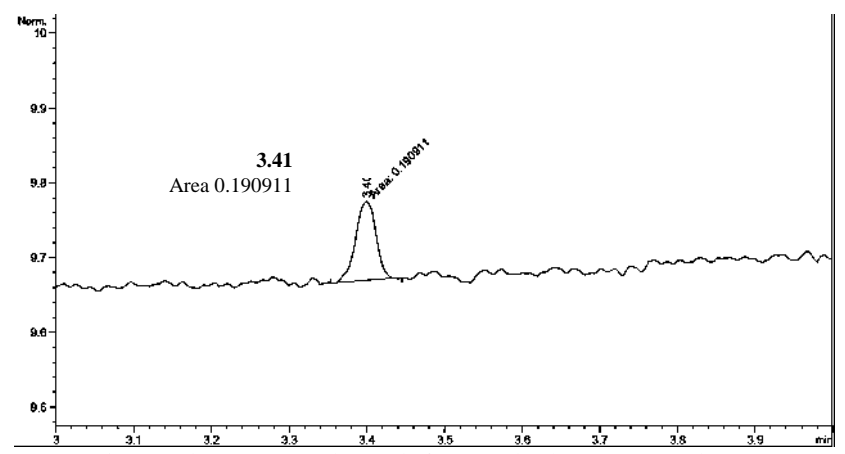

Fig. 2. Chromatograph result for standard $10 \mathrm{ppm}$ methane.

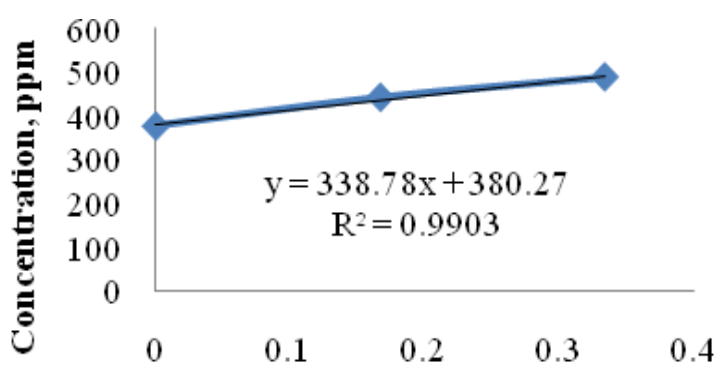

Time, hour

Fig. 3. Concentration of methane gas against time intervals of gas sampling.

\section{RESULTS AND DISCUSSION}

\section{A. Emission Rate of Methane at Different Growth Stages} of Paddy and Water Levels

During the period of gas sampling, there were four main growth stages of paddy involved for the two studied plots. The growth stages include seedling, tillering, stem elongation, and flowering. Table II shows the methane emission rate for Plot A and Plot B at the four different main growth stages.

TABLE II: Methane FluX of Plot A AND B in Different Stage of

\begin{tabular}{llll}
\multicolumn{4}{c}{ PADDY GROwTH } \\
\hline \hline $\begin{array}{l}\text { Days } \\
\text { After }\end{array}$ & Growth Stage & $\begin{array}{l}\text { Methane Flux } \\
\text { from } \\
\text { Plot A, } \\
\mathrm{mg} / \mathrm{m}^{2} \cdot \mathrm{h}\end{array}$ & $\begin{array}{l}\text { Methane Flux } \\
\text { from Plot B, } \\
\mathrm{mg} / \mathrm{m}^{2} \cdot \mathrm{h}\end{array}$ \\
\hline $8-14$ & Seedling & 0 & 0 \\
29 & Tillering & 2.16 & 1.11 \\
$56-64$ & Stem elongation & $9.61-10.06$ & $1.19-2.1$ \\
$80-84$ & Flowering & $10.85-21$ & $3.98-5.01$ \\
\hline \hline
\end{tabular}

As shown in Table II, there was no methane flux from both plots for days 8-14 after seeding, which indicated that during seedling stage of paddy, there was no methane emission from both paddy plots. At day 29, which was during the tillering stage of rice paddy, the methane emission rate was at 2.16 $\mathrm{mg} / \mathrm{m}^{2} \cdot \mathrm{h}$ for Plot A compared to Plot B that had only 1.11 $\mathrm{mg} / \mathrm{m}^{2} \cdot \mathrm{h}$ of methane flux.

A significant methane emission rate for Plot A was observed starting from day $56\left(9.61 \mathrm{mg} / \mathrm{m}^{2} \cdot \mathrm{h}\right)$ till day 64 $\left(10.06 \mathrm{mg} / \mathrm{m}^{2} \cdot \mathrm{h}\right)$ where paddies were at its stem elongation stage. However, the methane emission rate for Plot $\mathrm{B}$ remained low compared to Plot A from day $56\left(1.19 \mathrm{mg} / \mathrm{m}^{2} \cdot \mathrm{h}\right)$ till day $64\left(2.1 \mathrm{mg} / \mathrm{m}^{2} \cdot \mathrm{h}\right)$. These findings indicated that the implementation of water saving irrigation method for Plot B after day 50 had helped to decrease methane emission rate successfully.

During the flowering stage of paddy, an increased in methane emission rate from both plots was detected compared to previous growth stage (Table II). Methane emission rate from Plot A was $10.85 \mathrm{mg} / \mathrm{m}^{2} \cdot \mathrm{h}$ at day 80 after seeding and 21 $\mathrm{mg} / \mathrm{m}^{2} \cdot \mathrm{h}$ at day 84 , whereas for Plot $\mathrm{B}$, the methane emission rate was $3.98 \mathrm{mg} / \mathrm{m}^{2} \cdot \mathrm{h}$ at day 80 and $5.01 \mathrm{mg} / \mathrm{m}^{2} \cdot \mathrm{h}$ at day 84 . The methane emission rate for Plot A and Plot B is shown in Table II, after day 50 of seeding and with the introduction of water saving irrigation method to Plot B, the methane emission rate of Plot A was obviously higher than Plot B.

Most of the methane produced under the soil was emitted to the environment through the transportation occurred in the aeranchyma tissues of paddy [8]. Aeranchyma tissues are air channels in the plants which exist in the part of roots, stems and leaves. The quantity of aeranchyma tissues increased during stem elongation and flowering stage compared to tillering stage, and this caused the methane emission rate increased vividly for the paddy grew under normal water irrigation practice (Plot A). Besides, according to Singh [9], the root porosity which refers to aeranchyma tissues at root would grow bigger along the growth of paddy plant and reach maximum size during flowering stage of paddy. Hence, when the aeranchyma tissues grow bigger, the easier the gases including methane gas in the soil are carried out by the plant to the atmosphere [9]. Furthermore, the normal water irrigation method applied in Plot A created anaerobic environment for methanogens under the soil to produce more methane. As a result, the emission rate of methane gas quantified was the highest at day 84 of paddies growth, which the growth was during the flowering stage. However, comparing the methane flux from Plot A and Plot B (Table II), obviously the methane flux from Plot B was less than Plot A, especially after the implementation of water saving irrigation method, which was during the stem elongation and flowering stage. Less irrigation water to Plot B inhibited the production of methane gas by methanogen and hence the quantity of methane emitted to the surrounding could be minimized.

After the water saving irrigation method was applied to Plot B, only slight increment of methane flux for Plot B was detected along the growth of paddy, ranging from 1.10 $\mathrm{mg} / \mathrm{m}^{2} \cdot \mathrm{h}$ to $5 \mathrm{mg} / \mathrm{m}^{2} \cdot \mathrm{h}$. On the other hand, there was a significant increment of methane emission in Plot $\mathrm{A}$, ranging from $9.61 \mathrm{mg} / \mathrm{m}^{2} \cdot \mathrm{h}$ to $21 \mathrm{mg} / \mathrm{m}^{2} \cdot \mathrm{h}$ with the increased water level from January until March 2014. As a summary, the methane emission from flooded paddy field (Plot A) was $74 \%$ higher than non-flooded paddy field (Plot B).

The methane fluxes obtained from Plot A and Plot B calculated in average were $7.67 \mathrm{mg} / \mathrm{m}^{2} \cdot \mathrm{h}$ and $1.91 \mathrm{mg} / \mathrm{m}^{2} \cdot \mathrm{h}$ respectively and these results were comparable with studies of rice paddy fields in most Asia countries listed in Table III.

TABLE III: METHANE FLUXES FOR PADDY FIELDS IN DIFFERENT COUNTRIES

\begin{tabular}{llll}
\hline \hline $\begin{array}{l}\text { Average range } \\
\text { of methane flux, } \\
\mathrm{mg} / \mathrm{m}^{2} \cdot \mathrm{h}\end{array}$ & China [7] & Japan [10] & $\begin{array}{l}\text { Malaysia } \\
\text { (Current } \\
\text { Study) }\end{array}$ \\
\cline { 2 - 4 } & $0.88-4.9$ & $0.55-4.83$ & $1.91-7.67$ \\
\hline \hline
\end{tabular}

Similar water saving irrigation practice in rice paddy field studied by Yang [7] in China had shown that the paddy field with water-saving irrigation method had effectively reduced $66.7 \%$ of methane emission compared to flooding irrigation paddy fields. The study of Minamikawa [8] showed that 
during the drainage of paddy fields, the methane emission remained low and there was significant increase of methane flux after drainage. Based on Table III, the average range of methane emission rate detected in both Plot A and Plot B, located at Sik, Kedah Malaysia was relatively high compared to China [7] and Japan [10]. This might due to the climate condition occurred in Malaysia, which is consistently hot and humid weather compared to Japan and China. This climate condition is more favourable for active methanogenesis activity because methanogenesis activity favours high temperature as methanogens are thermophiles that tend to be more active in decomposing organic matters in soils at higher temperature. Hence, higher methane emission rate was observed in Malaysia.

\section{CONCLUSION}

The present study focuses on the methane quantification for paddy fields. The conventional water irrigation method of paddy field could contribute to methane emission significantly. Therefore, with the aim to reduce the methane emission, water saving irrigation method was applied to the paddy trial plots and methane emission rate for both plots with different water irrigation practices was compared. For water saving irrigation method, only sufficient water was supplied to the trial plot after 50 days of seeding. Along the experiment the methane emission rate detected for plot using the water saving irrigation method was relatively low compared to the plot which was always flooded.

As a conclusion, water level for paddy field played an important role on methane emission rate. The methane emission from flooded paddy field was $74 \%$ higher than non-flooded paddy field. Previous studies in China [5] had proven that there was no difference in rice yields between traditional flooding paddies and water saving irrigation paddies. This implies that non-flooded fields not only can reduce water wastage, but also can reduce methane flux and guarantee good harvest.

\section{ACKNOWLEDGMENT}

This research work was supported by NestléManufacturing (M) Sdn Bhd. The invaluable advice, guidance and the enormous patience from Nestlé management team led by Mr. Yong Lee Keng and partners such as One Goodearth Sdn. Bhd. throughout the development of the research are gratefully acknowledged. The gas sampling at Sik, Kedah were assisted by Nestlé's farmers and their effort during gas sampling and chamber setup are acknowledged.

\section{REFERENCES}

[1] H. S. Eggleston, L. Buendia, K. Miwa, T. Ngara, and K. Tanabe, "Guidelines for national greenhouse gas inventories," National Greenhouse Gas Inventories Programme, IGES, Japan, 2006.

[2] B. Metz, O. R. Davidson, and P. R. Bosch, "Climate change: Mitigation," Contribution of Working Group III to the Fourth Assessment Report of the Intergovernmental Panel on Climate Change, Cambridge: Cambridge University Press, 2007.

[3] E. T. Epule, C. Peng, and N. M. Mafany, "Methane emissions from paddy rice fields: Strategies towards achieving a win-win sustainability scenario between rice production and methane emission reduction," Journal of Sustainable Development, vol. 4, no. 6, pp. 188-196, December 2011.
[4] A. Hadi, K. Inubushi, and K. Yagi, "Effect of water management on greenhouse gas emissions and microbial properties of paddy soils in Japan and Indonesia," Paddy and Water Environment, vol. 8, no. 4, pp. 319-324, 2010.

[5] O. A. Oyewole, "Microbial communities and their activities in paddy fields: A review," Journal of Veterinary Advances, vol. 2, no. 2, pp. 74-80, 2012

[6] M. M. H. Oliver, M. S. U. Talukder, and M. Ahmed, "Alternate wetting and drying irrigation for rice cultivation," Journal of the Bangladesh Agricultural University, vol. 6, no. 2, pp. 409-414, 2008.

[7] S. H. Yang, S. Z. Peng, J. Z. Xu, Y. F. Luo, and D. X. Li, "Methane and nitrous oxide emissions from paddy field as affected by water-saving irrigation," Physics and Chemistry of the Earth, vol. 53-54, pp. 30-37, 2012.

[8] H. Schütz, A. Holzapfel-Pschorn, R. Conrad, H. Rennenberg, and W. Seiler, "A three-year continuous record on the influence of daytime, season, and fertilizer treatment on methane emission rates from an Italian rice paddy," Journal of Geophysical Research, vol. 94, pp. 16405-16416, 1989.

[9] S. Singh, J. Singh, and A. Kashyap, "Methane flux from irrigated rice fields in relation to crop growth and N-fertilization," Soil Biology and Biochemistry, vol. 31, pp. 1219-1228, 1999.

[10] K. Minamikawa and N. Sakai, "The effect of water management based on soil redox potential on methane emission from two kinds of paddy soils in Japan," Agriculture, Ecosystems and Environment, vol. 107, pp. 397-407, 2005.

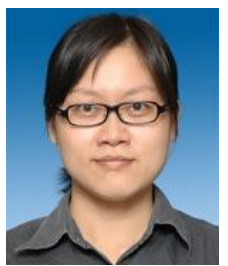

Lo Po Kim was born in Malaysia. She got her bachelor degree in engineering (hons) chemical engineering and the doctor of philosophy study was majored in bioprocess engineering, both studies in Universiti Teknologi Malaysia.

Currently she is an assistant professor in Petrochemical Engineering Department in Faculty of Engineering and Green Technology, Universiti Tunku (Abdul Rahman UTAR), Kampar, Perak Malaysia. Besides, she is also the deputy dean for R\&D and postgraduate programme for the faculty. Her main research area mainly related to bioprocess engineering and biotechnology, such as enzyme biotechnology, microbial fuel cell, waste water treatment and biogas production.

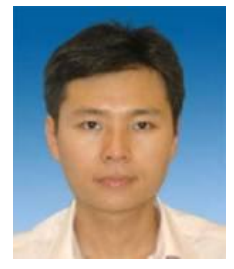

Ng Choon Aun was born in Malaysia. His bachelor degree achieved was bachelor of engineering (hons) (civil - environmental), the master degree was master of engineering (civil - environmental management), both in Universiti Teknologi Malaysia. Dr Ng's doctor of philosophy was majored in environmental engineering, Nanyang Technological University, Singapore.

Currently he is an assistant professor in Environmental Engineering Department in Faculty of Engineering and Green Technology, Universiti Tunku Abdul Rahman (UTAR), Kampar, Perak Malaysia. Besides, he is also the deputy dean for Academic Development \& Undergraduate Programmes for the faculty. His main research area mainly related domestic wastewater treatment using membrane bioreactor system, and water irrigation system for water saving and management.

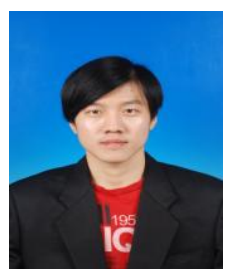

Chew Thiam Leng was born in Malaysia. His bachelor degree achieved was bachelor of engineering (hons) (chemical engineering), as well as the doctor of philosophy, which was majored in chemical engineering too, both completed in Universiti Sains Malaysia, Nibong Tebal.

Currently he is senior lecturer in Chemical Engineering Department in Faculty of Engineering, Universiti Teknologi Petronas (UTP), Tronoh, Perak Malaysia. Besides, he is also a member for $\mathrm{CO}_{2}$ management group in UTP. His main research area is mainly related to greenhouse gas absorption, separation and management.

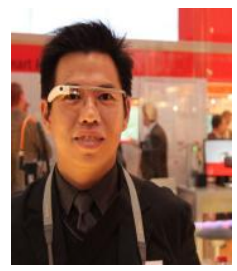

Tan Sze Pin was born in Malaysia. His bachelor degree was in electrical engineering in University of Malaya in year 1999, and his master of enineering was in microelectronics, achieved in Multimedia University (Malaysia), in year 2008.

Mr Tan is now pursuing his doctor of philosophy study. His research is related to using microorganism for palm oil mill effluent treatment, and application of microorganism for agricultural activities. 


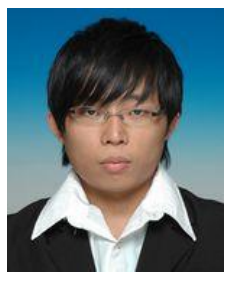

Lim Wai Zeng was born in Malaysia. His bachelor degree was in petrochemical engineering in Faculty of Engineering and Green Technology, Universiti Tunku Abdul Rahman, Kampar, Perak Malaysia, in year 2014.

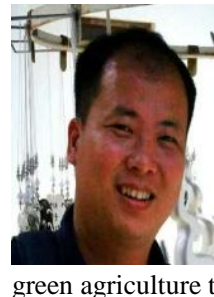

Chong Chin Yin was born in Malaysia. His bachelor degree was in food science and technology in Universiti Putra Malaysia. Currently he is working as an agricultural officer in Nestlé Manufacturing (M) Sdn Bhd.

His duty is not only to ensure that the agricultural products is fit to the specification required by Nestle Manufacturing (M) Sdn Bhd, but also helps to promote green agriculture technology implementation. 